\title{
PENGARUH STRUKTUR PENGENDALIAN INTERNAL, TATA KELOLA DAN ANALISIS RISIKO KEUANGAN TERHADAP EFEKTIVITAS PENYALURAN KREDIT PADA KOPERASI SIMPAN PINJAM DI KABUPATEN ACEH BESAR
}

\author{
Suci Hariyat ${ }^{1}$, Fazli Syam BZ ${ }^{* 2}$, Jhon Andra Asmara ${ }^{3}$ \\ ${ }^{1,2}$ Program Studi Akuntansi Fakultas Ekonomi Universitas Syiah Kuala \\ e-mail: Sucihariyati94@gmail.com ${ }^{1}$,FazliSyambz@gmail.com ${ }^{* 2}$, jhon.andra@ unsyiah.ac.id ${ }^{3}$ \\ * Corresponding Author
}

\begin{abstract}
The purpose of this study was to determine the effect of internal control structures, governance, and financial risk analysis on the effectiveness of credit distribution to savings and loan cooperatives in Aceh Besar District. The data used in this study are primary data using a quantitative approach. This study uses purposive sampling method in determining the sample, and there are 10 cooperatives that become samples that meet the criteria.Based on the research results, it shows that the structure of internal control, governance, and financial risk analysis together has a significant effect on the effectiveness of lending. The magnitude of the influence of internal control, governance and financial risk analysis on the effectiveness of lending was 63.8\%. The internal control structure has a significant effect on the effectiveness of lending. Governance does not have a significant effect on the effectiveness of lending. Financial risk analysis has no significant effect on the effectiveness of lending
\end{abstract}

Keywords: Internal Control Structure, Governance, Financial Risk Analysis, Effectiveness of Lending

\section{Pendahuluan}

Salah satu alat yang dapat membantu perekonomian masyarakat adalah koperasi. Menurut Kasmir (2013) koperasi merupakan sekelompok orang yang memiliki tujuan yang sama yang didasari asas kekeluargaan dan saling gotong royong antara anggota guna membantu satu sama lain. Koperasi didirikan untuk membantu para anggotanya yang memerlukan bantuan baik berbentuk barang ataupun pinjaman. Salah satu unit usaha koperasi adalah pemberian kredit simpan pinjam. Koperasi simpan pinjam merupakan lembaga keuangan yang berfungsi menyimpan dana dari masyarakat dan menyalurkan kembali melalui kredit. Dalam hal ini penyaluran kredit merupakan usaha yang paling utama di koperasi, oleh karena itu koperasi perlu memberikan penilaian atau mengadakan analisis kredit terhadap peminjam yang nantinya akan memberi keyakinan bahwa peminjam manpu mengembalikan kredit yang diberikan (Yesti dan Iwan, 2016).

Masalah utama yang sering terjadi dalam penyaluran kredit adalah masalah keamanan karena berkemungkinan terjadinya risiko kemacetan pembayaran kredit. Terjadinya kemacetan kredit akan berakibat buruk terhadap kelangsungan operasional koperasi dan nantinya akan menyebabkan koperasi bangkrut seperti yang terjadi di Batang sebanyak 150 koperasi ditutup kerena kredit macet (Jateng.com, 2017), begitupun juga yang terjadi di Solo 32 koperasi mati suri dikarenakan minimnya partisipasi dari anggota serta banyak koperasi yang terlibat kredit macet (Okezone Economy.com, 2013). Selain masalah keamanan koperasi juga memiliki masalah pelik lainnya seperti: tidak memiliki kekuatan anggota dalam menentukan arah koperasi, tidak memiliki anggota yang kompeten dalam bidang manajemen, tidak memiliki tata kelola yang baik, dan kualitas koperasi masih beragam dalam pengembangan strategi kerjasama dengan pihak luar dan pihak lain, bahkan kinerja manajemen yang masih kurang.

Untuk mencegah terjadinya persoalan di atas maka diperlukan suatu Struktur Pengendalian Internal, Tata Kelola, dan Analisa Resiko Keuangan yang baik guna tersalurkannya kredit yaang efektif. Struktur Pengendalian Internal merupakan kebijakan dan prosedur yang ditetapkan untuk memperoleh 
keyakinan memadai bahwa tujuan satuan usaha spesifik akan dapat dicapai (Mulyadi, 2002:181). Terdapatnya Struktur Pengendalian Internal diharapkan koperasi dapat bekerja atau beroperasi sesuai dengan ketentuan yang berlaku, jika dipatuhi peraturan dan kebijakan maka penyimpanan dapat dihindari.

Tata kelola (Good Corporate Governance) merupakan prinsip yang mengendalikan dan yang mengarahkan koperasi agar mencapai keseimbangan antara kekuatan serta kewenangan dalam memberikan pertanggung jawaban kepada para shareholder khususnya, dan stakeholders pada umumnya. Hal ini dimaksudkan untuk mengatur kewenangan direktur, manajer, pemegang saham, dan pihak lain yang berhubungan dengan perkembangan koperasi di lingkungan tertentu," kata Andi Syamsul Bahri, KSP Pandawa Mandiri Group (BeritaSatu.com, 2016).

Analisis Risiko Keuangan merupakan segala macam risiko yang berkaitan dengan keuangan, seperti risiko suku bunga, dan risiko likuiditas. Dalam menyetujui permintaan kredit, pihak koperasi harus mempertimbangkan resiko kemacetan kredit yang mungkin terjadi. Pihak koperasi sebelum mengambil keputusan untuk memberi dan menolak permintaan kredit dari anggota, perlu mengadakan analisis terlebih dahulu terhadap kondisi keuangan dari pihak peminjam yang mengajukan kredit, guna mengukur kemampuan peminjam untuk membayar kembali hutangnya beserta beban-beban bunganya

\section{Kajian Pustaka}

\section{Struktur Pengendalian Internal}

Menurut COSO (Committee of sponsoring Organization) 2013, menyatakan pengendalian internal adalah proses, dipengaruhi oleh dewan entitas direksi, manajemen dan personel lain, yang dirancang untuk memberikan keyakinan memadai tentang pencapaian tujuan dalam Kategori berikut: efektivitas dan efisiensi operasi, keandalan pelaporan keuangan, dan kepatuhan terhadap hukum yang berlaku dan peraturan.

Komponen pengendalian internal merupakan proses untuk menghasilkan pegendalian yang memadai. Agar tujuan pengendalian tercapai, koperasi harus mempertimbangkan komponen-komponen pengendalian internal yang harus digunakan. Adapun komponen-komponen pengendalian internal menurut Arens (2008) adalah :

a. Lingkungan Pengendalian terdiri dari tindakan, kebijakan, dan prosedur yang mencerminkan sikap dari manajemen puncak, para direktur, dan pemilik dari suatu entitas mengenai pengendalian internal dan pentingnya komponen bagi entitas itu.

b. Penilaian Risiko adalah identifikasi manajemen dan analisis resiko yang relevan dengan persiapan laporan keuangan yang sesuai dengan prinsip berlaku umum.

1. c. Aktivitas Pengendalian adalah kebijakan dan prosedur yang dibuat untuk memberikan keyakinan bahwa petunjuk yang dibuat oleh manajemen dilaksanakan.

c. Informasi dan Komunikasi, sistem informasi yang relevan dengan tujuan laporan keuangan yang meliputi sistem akuntansi.

d. Pemantauan adalah proses penilaian kualitas kinerja struktur pengendalian intern sepanjang waktu.

\section{Tata Kelola}

Menurut Forum for Corporate Governance in Indonesia (FCGI), Good Governance (tata kelola) adalah seperangkat peraturan yang menetapkan hubungan antara pemegang saham, pengurus, kreditur, pemerintah, karyawan serta para pemegang kepentingan intern dan ekstern lainnya sehubungan dengan hak-hak dan kewajiban mereka, atau dapat dikatakan sebagai suatu sistem yang mengarahkan dan mengendalikan perusahaan (Sari dkk, 2015).

Dalam hubungannya dengan tata kelola Badan Usaha Milik Negara (BUMN), Menteri Negara juga mengeluarkan Keputusan Nomor Kep-117/MMBU/2002 tentang Penerapan Tata Kelola (Tjager dkk.,2003: Agoes, 2014). Ada lima prinsip menurut keputusan ini, yaitu:
a. Perlakuan yang setara (fairness)
b. Prinsip transparansi (disebut juga pronsip keterbukaan).
c. Prinsip akuntabilitas
d. Prinsip responsibilitas (lebih sering disebut prinsip tanggung jawab)
e. Kemandirian 


\section{Analisis Risiko Keuangan}

Munawir (2010:64) analisis rasio keuangan menggambarkan suatu hubungan tertentu dengan jumlah lain, dan sangat berguna untuk menjelaskan ataupun memberikan gambaran bagi pihak yang menganalisis mengenai kondisi baik atau buruknya keuangan perusahaan.

Menurut Matousi dan Abdeimoua (2009:124) dalam menilai usaha debitur perlu diperhatikan rasio keuangan yaitu sebagai berikut:

a. Kinerja Operasi ( operating performance) merupakan rasio yang bermanfaat untuk mengukur efisiensi kegiatan operasi perusahaan.

b. Kemampuan membayar utang (debt service capability) mencerminkan kemampuan suatu perusahaan atau orang untuk menyelesaikan kewajibannya membayar utang

c. Modal kerja (working capital) merupakan modal yang diperlukan untuk membiayai seluruh kegiatan supaya usaha berjalan sesuai dengan rencana yang telah dibuat.

d. Keuntungan (profitability) sebagai alat ukur kemampuan perusahaan untuk menghasilkan laba (profit) dari pendapatan (earning) yang berhubungan dengan penjualan, aset dan ekuitas

\section{Efektivitas Penyaluran Kredit}

Munawaroh (2011) menjelaskan bahwa penyaluran kredit akan dapat dikatakan efektif apabila kredit yang diberikan dapat kembali sesuai waktu yang ditetapkan beserta bunga yang sudah ditetapkan. Prioritas penyaluran kredit pun menentukan keefektifan pemberian kredit, jika kredit yang diberikan betul-betul tepat sasaran dan tepat guna, maka efektifitas penyaluran kredit akan tercapai.

Menurut Makmur (2011:7) aspek-aspek yang digunakan sebagai ukuran dalam efektifitas penyaluran kredit sebagai berikut:
a. Aspek ketepatan sasaran.
b. Aspek ketepatan waktu.
c. Aspek ketepatan jumlah.
d. Aspek ketepatan beban kredit.
e. Aspek ketepatan prosedur

\section{Metode Penelitian Desain Penelitian}

Penelitian ini menggunakan pendekatan kuantitif, (Sugiyono, 2014) menjelaskan bahwa penelitian kua nitatif adalah Metode penelitian yang berdasarkan pada prinsip positivisme, dipakai dan dimanfaatkan untuk meneliti pada populasi atau sampel tertentu, teknik pengambilan sampel yang lazimnya dijalankan secara random, pengumpulan data menggunakan instrumen penelitian penelitian, analisis data bersifat kuantitatif/statistik dengan sasaran untuk menguji hipotesis yang telah diterapkan.

\section{Populasi dan Sampel Penelitian}

Sugiono (2014:119) menjelaskan bahwa populasi merupakan wilayah generalisasi kuantitas dan karakteristik tertentu yang ditetapkan oleh peneliti untuk dipelajari dan kemudian ditarik kesimpulannya. Populasi dalam penelitian ini adalah seluruh koperasi yang bergerak di bidang Simpan Pinjam yang berada di Kabupaten Aceh Besar yang berjumlah 22 koperasi. Pengambilan sampel dalam penelitian ini dengan menggunakan teknik purposive sampling yaitu suatu metode penarikan sampel probabilitas yang dilakukan dengan kriteria tertentu. Adapun Jumlah sampel dalam penelitian ini adalah 10 Koperasi.

\section{Data dan Teknik Pengumpulan Data}

Data yang akan digunakan dalam penelitian ini adalah data primer. Data diperoleh berdasarkan penyebaran kuisioner kepada pengurus koperasi yang dijadikan sebagai sampel dan responden dalam penelitian. Pengumpulan data dilakukan dengan cara membagikan kuisioner. Kuisioner merupakan metode pengumpulan data yang dilakukan dengan cara membuat sekumpulan pertanyaan atau pernyataan tertulis kepada responden untuk dijawabnya( Sugiyono, 2013: 193.

\section{Metode Analisis}

Metode analisis regresi linear berganda berfungsi untuk menguji pengaruh 2 variabel yaitu variabel independen dan variabel depeden. Dalam penelitian ini variabel independennya adalah struktur pengendalian internal (X1), tata kelola (X2), dan 
analisis risiko keuangan (X3), sedangkan variabel dependennya adalah efektivitas penyaluran kredit (Y).

Metode analisis ini digunakan untuk menguji “ Pengaruh struktur pengendalian internal, tata kelola, dan analisis risiko keuangan terhadap efektivitas penyaluran kredit pada koperasi simpan pinjam Di Kabupaten Aceh

Besar". Model ini dipilih karena penelitian ini menggunakan lebih dari satu variabel yaitu 3 variabel independen dan 1 variabel dependen. Analisis data penelitian ini akan diolah menggunakan bantuan SPSS (statistical package for social srence) dengan model persamaan regresi sebagai berikut:

$$
\mathrm{Y}=\mathrm{a}+\mathrm{b} 1 \mathrm{X} 1+\mathrm{b} 2 \mathrm{X} 2+\mathrm{b} 3 \mathrm{X} 3+\mathrm{e}
$$

Dimana:

$\begin{array}{ll}\mathrm{Y} & =\text { Efektivitas Penyaluran Kredit } \\ \mathrm{A} & =\text { Konstanta } \\ \mathrm{b} 1, \mathrm{~b} 2, \mathrm{~b} 3, \mathrm{~b} 4 & =\text { Koefisien Regresi } \\ \mathrm{X} 1 & =\text { Struktur Pengendalian Internal } \\ \mathrm{X} 2 & =\text { Tata Kelola }\end{array}$

$$
\begin{array}{ll}
\mathrm{X} 3 & =\text { Analisis Risiko Keuangan } \\
\mathrm{E} & =\text { Error }
\end{array}
$$

\section{Hasil dan Pembahasan}

\section{Penyebaran Kuisioner}

Pengumpulan data dilakukan dengan menggunakan kuesioner yang disebarkan secara langsung ke 10 koperasi simpan pinjam yang berada di Kabupaten Aceh Besar. Penyebaran kuesioner dilakukan sejak tanggal 22 Januari 2020 sampai tanggal 11 febaruari 2020 yang membutuhkan waktu selama 3 minggu untuk mengumpulkan kuesioner yang berjumlah 50 lembar kuesioner.

Berdasarkan data yang dikumpulkan dalam penelitian ada 60 responden yang menjadi target penelitian, tapi hanya 50 responden yang bersedia mengisi kuisioner. Rincian pendistribusian kuesioner bisa diperhatikan lebih jelas pada tabel 1. Seluruh data yang diperoleh selanjutnya ditabulasi dan diolah menggunakan program SPSS (Statistical Package for Social Science) 20.

Tabel 1

Rincian pendistribusian kuesioner

\begin{tabular}{|c|l|c|c|}
\hline No & \multicolumn{1}{|c|}{ Responden } & $\begin{array}{c}\text { Distribusi } \\
\text { Kuesioner }\end{array}$ & $\begin{array}{c}\text { Kuesioner } \\
\text { Kembali }\end{array}$ \\
\hline 1. & Kopsyah BQ Karya Insan Sejahtera & 6 & 6 \\
\hline 2. & Koperasi Syariah Baitul Qiradh Abu Indrapuri & 5 & 5 \\
\hline 3. & Koperasi BPR Ingin Jaya & 20 & 20 \\
\hline 4. & Koperasi Simpan Pinjam Dana Mandiri Syariah & 5 & 0 \\
\hline 5. & Koperasi Syariah Mitra Niaga & 8 & 8 \\
\hline 6. & Koperasi BQ Al-Istiqamah & 2 & 0 \\
\hline 7. & Koperasi BMT Taman Indah & 4 & 4 \\
\hline 8. & Koperasi Pertanian Tiga Sekawan & 7 & 7 \\
\hline 9. & Koperasi Syariah Mandiri Darussalam & 2 & 0 \\
\hline 10. & Koperasi Bina Mandiri & 1 & 0 \\
\hline Total & 60 & 50 \\
\hline Persentase & $100 \%$ & $83.3 \%$ \\
\hline
\end{tabular}

Sumber: Data Primer, Diolah 2020.

\section{Model Persamaan Regresi Linear Berganda}

Untuk dapat mengetahui pengaruh variabelvariabel independen terhadap variabel dependen maka digunakanlah analisis regresi berganda dengan bantuan perangkat program SPSS yang secara rinci disajikan pada lampiran. Variabel independen dalam penelitian ini adalah struktur pengendalian internal $\left(\mathrm{X}_{1}\right)$, tata kelola $\left(\mathrm{X}_{2}\right)$ dan analisis risiko keuangan (X3), sedangkan variabel dependen adalah efektivitas penyaluran kredit $(\mathrm{Y})$. Hasil pengujian regresi linear berganda dapat dilihat pada Tabel 2 . 
Tabel 2

Hasil Pengujian Regresi Linear Berganda

\begin{tabular}{|c|c|c|c|c|c|c|}
\hline \multirow{2}{*}{\multicolumn{2}{|c|}{ Model }} & \multicolumn{2}{|c|}{$\begin{array}{c}\text { Unstandardized } \\
\text { Coefficients }\end{array}$} & $\begin{array}{c}\text { Standardized } \\
\text { Coefficients }\end{array}$ & \multirow[t]{2}{*}{$\mathbf{t}$} & \multirow[t]{2}{*}{ Sig. } \\
\hline & & $\bar{B}$ & $\begin{array}{l}\text { Std. } \\
\text { Error }\end{array}$ & Beta & & \\
\hline \multirow{4}{*}{1} & (Constant) & 14,495 & 3,929 & & 3,689 &, 001 \\
\hline & $\begin{array}{l}\text { Struktur Pengendalian } \\
\text { Internal X1 }\end{array}$ & ,623 & ,119 & ,930 & 5,256 & ,000 \\
\hline & Tata Kelola X2 &,- 045 & ,087 &,- 082 &,- 519 & ,606 \\
\hline & $\begin{array}{l}\text { Analisis Risiko } \\
\text { Keuangan X3 }\end{array}$ &,- 072 & ,086 &,- 100 &,- 840 & ,405 \\
\hline
\end{tabular}

a. Dependent Variable: Efektivitas Penyaluran Y

Hasil output SPSS (coefficients), dapat diperoleh persamaan regresi berganda (multiple regression) sebagai berikut

$$
\mathrm{Y}=14,495+, 623 \mathrm{X} 1-, 045 \mathrm{X} 2-, 072 \mathrm{X} 3+\mathrm{e}
$$

Dari persamaan regresi dapat diketahui hasil penelitian dari masing-masing koefisien yaitu untuk konstanta $(\mathrm{a}=14,495)$, artinya jika faktor-faktor struktur pengendalian internal $\left(\mathrm{X}_{1}\right)$, tata kelola $\left(\mathrm{X}_{2}\right)$, dan analisis risiko keuangan $\left(\mathrm{X}_{3}\right)$ dianggap konstan, maka besarnya efektivitas penyaluran kredit pada koperasi simpan pinjam di Aceh Besar adalah sebesar 14,495. struktur pengendalian internal $\left(\mathrm{X}_{1}\right)$, mempunyai pengaruh terhadap efektivitas penyaluran kredit pada koperasi simpan pinjam di kabupaten Aceh Besar dengan koefisien variabel sebesar 0,623. Sedangkan untuk varibel tata kelola $\left(\mathrm{X}_{2}\right)$, dan analisis risiko keuangan $\left(\mathrm{X}_{3}\right)$, berpengaruh negatif terhadap efektivitas penyaluran kredit pada koperasi simpan pinjam di Kabupaten Aceh Besar dengan koefisien variabel masing-masing sebesar -0,045 (X2) dan -,072 (X3).

Tabel 3

Model Summary

\begin{tabular}{|l|r|r|r|r|}
\hline Model & \multicolumn{1}{|c|}{ R } & \multicolumn{1}{|c|}{ R Square } & Adjusted R Square & \multicolumn{1}{c|}{$\begin{array}{c}\text { Std. Error of the } \\
\text { Estimate }\end{array}$} \\
\hline 1 &, $799^{\mathrm{a}}$ &, 638 &, 615 & 2,71415 \\
\hline
\end{tabular}

a. Predictors: (Constant), Total Analisis Risiko Keuangan X3, Total Tata Kelola X2,

Total Struktur Pengendalian Internal X1

Sumber: Data Diolah (2020)

Berdasarkan hasil analisis diketahui koefisien determinasi (R2) sebesar 0,638, yang artinya bahwa sebesar 63,8\% efektivitas penyaluran kredit dipengaruhi oleh variabel faktor struktur pengendalian internal (X 1), tata kelola (X2), dan analisis risiko keuangan (X3), sedangkan sisanya dipengaruhi oleh variabel-variabel lain yang tidak digunakan dalam penelitian

\section{Uji Simultan (Uji F)}

Pengujian secara simultan atau uji F dilakukan untuk menguji hipotesis mengenai struktur pengendalian internal, tata kelola, dan analisis risiko keuangan secara bersama-sama terhadap efektivitas penyaluran kredit. Jika F- hitung > F-tabel dengan tingkat signifikan 5\% menunjukkan bahwa secara simultan variabel independen berpengaruh signifikan terhadap variabel dependen, begitu juga sebaliknya. Hasil pengujian secara simultan dapat dilihat pada tabel 4 
Tabel 4

Pengujian Hipotesis Secara Simultan

ANOVA

\begin{tabular}{|c|c|c|c|c|c|}
\hline Model & Sum of Squares & df & Mean Square & $\mathbf{F}$ & Sig. \\
\hline \begin{tabular}{|cc} 
& Regression \\
1 & Residual \\
& Total
\end{tabular} & $\begin{array}{l}610,592 \\
346,231 \\
956,824\end{array}$ & $\begin{array}{r}3 \\
47 \\
50\end{array}$ & $\begin{array}{r}203,531 \\
7,367\end{array}$ & 27,629 &, $000^{\mathrm{b}}$ \\
\hline
\end{tabular}

a. Dependent Variable: Efektivitas Penyaluran Y

b. Predictors: (Constant), Analisis Risiko Keuangan X3, Tata Kelola X2, Struktur

Pengendalian Internal X1

Sumber: Data Diolah (2020)

Berdasarkan hasil olah data spss seperti tabel diatas nilai $\mathrm{F}$ hitung sebesar 27,629 dengan nilai probabilitas $\quad(\mathrm{sig})=0,000 . \quad$ Nilai Fhitung $(27,269)>$ Ftabel $(2,81)$, dan nilai sig. lebih kecil dari nilai probabilitas 0,05 atau nilai $0,000<0,05$; maka H01, H02, H03 diterima, berarti secara bersama-sama (simultan) Struktur Pengendalian Internal, Tata Kelola, Analisis Risiko Keuangan berpengaruh signifikan terhadap Efektivitas Penyaluran Kredit.

\section{Uji Parsial (Uji T)}

Pengujian regresi secara parsial (uji t)

Tabel 5

Hasil Uji Pasrial

\begin{tabular}{|l|r|r|}
\hline \multicolumn{1}{|c|}{ Model } & T hitung & \multicolumn{1}{c|}{ Sig. } \\
\hline (Constant) & 3,689 & .001 \\
\multirow{2}{*}{1 Struktur pengendalian internal } & 5,256 & .000 \\
Tata kelola &,- 519 &, 606 \\
Analisis risiko keuangan &,- 840 &, 405 \\
\hline
\end{tabular}

a. Dependent Variable: efektivitas penyaluran kredit Sumber: Data Diolah (2020)

Berdasarkan hasil tabel diatas hipotesis nol $(\mathrm{H} 01)$ ditolak dan hipotesis alternatif $\left(\mathrm{H}_{\mathrm{a}} \mathrm{l}\right)$ diterima untuk variabel struktur pengendalian internal karena 5,256>1,67. Artinya, struktur pengendalian internal mempunyai pengaruh terhadap efektivitas penyaluran kredit. Variabel tata kelola hipotesis nol (H02) diterima dan hipotesis alternatif $\left(\mathrm{H}_{\mathrm{a}} 1\right)$ ditolak karena $-, 519<1,67$. Artinya, tata kelola tidak mempunyai pengaruh terhadap efektivitas penyaluran kredit. Variabel Analisis risiko keuangan hipotesis nol dilakukan untuk mengetahui pengaruh masing-masing variabel bebas terhadap variabel terikat yaitu antara struktur pengendalian internal terhadap efektivitas penyaluran kredit, tata kelola terhadap efektivitas penyaluran kredit, dan analisis risiko keuangan terhadap efektivitas penyaluran kredit. Jika t- hitung > t-tabel dengan tingkat signifikan 5\% menunjukkan bahwa secara parsial variabel independen berpengaruh secara signifikan terhadap variabel dependen. Hasil pengujian secara parsial dapat dilihat pada tabel 5 
Berdasarkan hasil regresi berganda, nilai koefisien regresi menunjukkan bahwa struktur pengendalian internal berpengaruh terhadap efektivitas penyaluran kredit. Hal ini sesuai dengan hipotesis yang telah dibuat, yakni struktur pengendalian internal berpengaruh terhadap efektivitas penyaluran kredit. Hasil penelitian ini konsisten atau sesuai dengan hasil penelitian sebelumnya yang dijadikan referensi dalam penelitian ini, seperti penelitian yang dilakukan oleh Munawaroh (2011), yang menyatakan bahwa struktur pengendalian internal berpengaruh terhadap efektivitas penyaluran kredit. Sama halnya dengan hasil penelitian yang dilakukan oleh Dewa Putu dan Ketut Jati (2013) yang menyatakan bahwa struktur pengendalian internal berpengaruh signifikan terhadap penyaluran kredit dengan besarnya pengaruh sebesar $79,30 \%$.

Hasil penelitian ini bertolak belakang dengan hasil penelitian yang dilakukan oleh Welly (2015) dengan penelitian mengenai pengaruh struktur pengendalian intern, sistem pengendalian intern terhadap efektivitas penyaluran kredit pada perbankan syariah di Kota Palembang. Hasil penelitiannya adalah struktur pengendalian intern tidak berpengaruh positif terhadap efektivitas penyaluran kredit pada perbankan syariah di Kota Palembang. Hal ini disebabkan karena secara keseluruhan struktur pengendalian intern belum diterapkan secara optimal.

\section{Pengaruh tata kelola terhadap efektivitas penyaluran kredit pada koperasi simpan pinjam di Kabupaten Aceh Besar}

Berdasarkan hasil regresi berganda, nilai koefisien regresi menunjukkan bahwa tata kelola tidak berpengaruh signifikan terhadap efektivitas penyaluran kredit. Hasil penelitian ini bertolak belakang dengan penelitian yang dilakukan oleh Imam \& Ade (2017) tentang analisis pengaruh penerapan good corporate governance terhadap prosedur pemberian kredit dalam meningkatkan feebase. Hasil penelitiannya menunjukan adanya pengaruh positif antara penerapan GCG terhadap prosedur pemberian kredit. Penerapan GCG yang baik mendorong naiknya jumlah penyaluran kredit yang dapat dilihat dari laporan keuangan konsolidasi.
Hasil penelitian lainnya yaitu penelitian yang dilakukan oleh Tanri dkk (2017) tentang analisis prosedur pemberian kredit dengan menggunakan prinsip-prinsip good corporate governance pada PT. Bank Sulutgo. Hasil penelitiannya menunjukkan bahwa prinsip GCG belum seluruhnya diterapkan secara memadai seperti: prinsip tranparancy, accountability dan independency. Ketiga prinsip ini belum diterapkan secara optimal pada PT Bank Sulutgo. Selain itu hasil Penelitian yang dilakukan oleh Pradnyaswari et al., (2016) menyatakan bahwa prinsip- prinsip GCG memberikan pengaruh positif dan signifikan pada kinerja keuangan koperasi di kabupaten Klungkung. Semakin baik penerapan prinsip-prinsip GCG dalam koperasi maka semakin meningkat pula kinerja keuangan koperasi di kabupaten Klungkung, begitu juga sebaliknya semakin buruk penerapan prinsip-prinsip GCG maka kinerja keuangan koperasi akan turut mengalami penurunan.

Perbedaan penelitian ini dengan penelitian sebelumnya adalah pada penelitian ini menggunakan pendekatan kuantitatif yang dimana data yang diperoleh akan diolah menggunakan SPSS, sedangkan pada penelitian yang dilakukan oleh Imam \& Ade, dan Tanri dkk, menggunakan pendekatan kualitatif. Penelitian yang dilakukan Pradnyaswari et al., (2016) menggunakan pendekatan yang sama yaitu kuantitatif hanya saja sampel yang digunakan berbeda yaitu 78 koperasi dengan mengambil 3 responden di masingmasing koperasi sehingga total respondenya adalah 234 responden, sedangkan pada penelitian ini jumlah koperasi 10 dan responden secara keseluruhan sebanyak 50 orang. Sehingga berdasarkan perbedaan penelitian diatas menyebabkan hasil penelitian ini berbeda dengan hasil penelitian sebelumnya

\section{Pengaruh analisis risiko keuangan terhadap efektivitas penyaluran kredit pada koperasi simpan pinjam di Kabupaten Aceh Besar}

Berdasarkan hasil regresi berganda, nilai koefisien regresi menunjukkan bahwa analisis risiko keuangan tidak berpengaruh signifikan terhadap efektivitas penyaluran kredit. Hal ini bisa disebabkan karena jumlah responden yang sedikit yaitu 50 orang sehingga pada saat pengujian statistik tidak diperoleh bukti atau dukungan yang kuat supaya hipotesis nya 
positif. Hasil penelitian ini bertolak belakang dengan Penelitian yang dilakukan oleh Westwind et. al., (2015) tentang analisis laporan keuangan sebagai kriteria pemberian kredit oleh PT. Bank Tabungan Negara (PERSERO) TBK Cabang Manado menunjukkan bahwa penerapan prosedur analisis laporan laporan keuangan dalam pemberian kredit oleh bank BTN adalah baik, dimana terdapat penilaian resiko kredit dalam keputusan pemberian kredit. Pada penelitian ini menggunakan alat ukur yang berbeda dari Westwind et. al., (2015) yaitu: kinerja operasi, kemampuan membayar utang, modal kerja, dan keuntungan. Sedangkan Westwind et. al., (2015) menggunakan beberapa metode dan teknik analisis laporan keuangan, yakni: 1. Analisis rasio, 2. Analisis perbandingan neraca, 3. Analisis perbandingan laba rugi

\section{Kesimpulan dan Saran}

\section{Kesimpulan}

a. Struktur pengendalian internal, tata kelola, dan analisis risiko keuangan secara bersama-sama berpengaruh signifikan terhadap efektivitas penyaluran kredit. Besarnya pengaruh pengendalian internal, tata kelola dan analisis risiko keuangan terhadap efektivitas penyaluran kredit adalah $63,8 \%$.

b. Struktur pengendalian internal berpengaruh signifikan terhadap efektivitas penyaluran kredit. Hal ini berarti struktur pengendalian internal sudah cukup baik sehingga mampu memengaruhi efektivitas penyaluran kredit.

c. Tata kelola tidak berpengaruh signifikan terhadap efektivitas penyaluran kredit. Hal ini berarti penerapan tata kelola pada koperasi belum cukup baik sehingga belum mampu memengaruhi evektivitas penyaluran kredit

d. Analisis risiko keuangan tidak berpengaruh signifikan terhadap efektivitas penyaluran kredit. Hal ini berarti analisis risiko keuangan belum diterapkan dengan cukup baik sehingga tidak mampu memengaruhi efektivitas penyaluran kredit.

\section{Saran}

\section{Saran Akademis} $\begin{array}{lrrr}\text { a. Penelitian } & \text { selanjutnya } & \text { disarankan } & \text { untuk } \\ \text { menambah } & \text { variabel } & \text { bebasnya } & \text { atau }\end{array}$ menggunakan variabel lain yang bisa mempengaruhi efektivitas penyaluran kredit.

b. Penelitian ini menggunakan kuesioner dalam memperoleh data, apabila memungkinkan diharapkan pada penelitian selanjutnya untuk melakukan studi kasus di lapangan.

c. Penelitian selanjutnya disarankan agar menambahkan objek penelitian tidak hanya pada Kabupaten Aceh Besar, tetapi juga pada Kabupaten lainnya sebagai sampel yang akan diteliti.

\section{Saran Praktis}

a. Struktur pengendalian internal pada koperasi simpan pinjam di Kabupaten Aceh Besar sudah baik dan perlu dipertahankan serta ditingkatkan lebih baik lagi agar semakin efektivitas dalam penyaluran kredit.

b. Perlu dilakukan pelatihan dan pembinaan yang rutin kepada peminjam sesaat setalah dana dicairkan guna menekan besarnya kredit macet.

\section{Daftar Pustaka}

Agoes, Sukriesno dan Cenik Ardana. 2014. Etika Bisnis Dan Profesi. Tantangan Membangun Manusia Seutuhnya. Edisi Revisi. Jakarta: Salemba Empat.

Arens, Alvin A., Elder, dan Beasley. 2008. Auditing dan Jasa Assurance Pendekatan Terintegrasi Jilid 1. Edisi 12 Jakarta: Erlangga.

Beritasatu.Com. (2016). Pandawa Group Tekankan Pentingnya Tata Kelola Koperasi Simpan Pinjam. Retrieved $\quad$ From File://C:/Users/User/Downloads/ Pandawa Group Tekankan Pentingnya Tata Kelola Koperasi Simpan Pinjam Beritasatu.Com.Html

COSO. (2013). Internal Control - Integrated Framework. Kpmg, 1-8. https://doi.org/978-193735-239-4.

I Dewa Putu Gde Sumerta Yasa dan I Ketut Jati. 2013. Pengaruh Komponen Pengendalian Internal Kredit Pada Kredit Bermasalah BPR 
Di Kabupaten Buleleng. Jurnal Akuntansi Universitas Udayana 4.2 (2013): 315-331.

Institut Akuntan Publik Indonesia (IAPI), 2011. Standar Profesional Akuntan Publik. Jakarta: Salemba Empat.

Jateng.Com, A. (2017). $150 \quad$ Koperasi Di Batang Ditutup Karena Kredit Macet. Retrieved From.

File:///C:/Users/User/Downloads/150 Koperasi Di Batang Ditutup Karena Kredit Macet Antara Jateng.Htm

Makmur, 2011. Efektifitas Kebijakan kelembagaan Pengawasan. Bandung: , Refika Aditama.

Matoussi, Hamadi dan Aida Abdelmoula. 2009. "Using a Neural Network-Based Methodology for Credit-Risk Evaluation of a Tunisian Bank". Journal of Finance and Economics. Hal 118-140 Tunisia: University of Manouba.

Mulyadi. (2002). Auditing, Edisi Kelima, Cetakan Pertama. Jakarta: Salemba Empat.

Munawaroh. (2011). Peranan Pengendalian Internal dalam Menunjang Efektifitas Sistem Pemberian Kredit Usaha Kecil dan Menengah. ( Studi Kasus di Koperasi Pegawai BRI Cabang Kediri). STKIP PGRI Jombang. Jurnal Manajemen dan Kewirausahaan.

Munawir, S. 2010. Analisis Laporan Keuangan. Edisi Empat. Liberty. Yogyakarta.

Okezone Economy.Com. (2013). Kredit Macet, 32 Koperasi Di Solo Mati Suri. Retrieved $\quad$ From File:///C:/Users/User/Downloads/Kredit Macet, 32 Koperasi Di Solo Mati Suri Okezone Economy.Htm.

Pradynyaswari, Luh Gede Diah Ary dan I Gusti A. M. A. D Putri. (2016). Pengaruh PrinsipPrinsip Good Corporate Governance Pada Kinerja Keuangan Koperasi Di Kabupaten Klungkung. Bali: Fakultas Ekonomi dan Bisnis Universitas Udayana (Unud). E-Jurnal Akuntansi Universitas Udayana.

Sari, $d k k$. 2015. Pengaruh Efektifitas Sistem Pengendalian Internal, Ketaatan Aturan
Akuntansi, Persepsi Kesesuaian Kompensasi Dan Implementasi Good Governance Terhadap Kecenderungan Fraud. e-Journal S1 Ak Universitas Pendidikan Ganesha. Volume 3, No.1.

Sugiyono. (2013). Statistika untuk penelitian. Bandung: Alfabeta.

Sundarta, M. Imam, Ade Retno Nuraeni. 2017. Analisis Pengaruh Penerapan Good Corporate Governance Terhadap Prosedur Pemberian Kredit Dalam Meningkatkan Feebase studi Empiris Pada PT. Bank Central Asia Tbk Cabang KCU Margonda Depok. Jurnal Ilmiah Akuntansi dan Keuangan.

Tanrius, Tanri F dkk. 2017. Analisis Prosedur Pemberian Kredit Dengan Menggunakan Prinsip-Prinsip Good Corporate Governance Pada PT. Bank Sulutgo. Jurnal Berkala Ilmiah.

Tjager, I Nyoman dkk. 2003. Corporate Governance: Tantangan dan Kesempatan Bisnis Indonesia. Jakarta: PT Prenhallindo.

Welly. (2015). Pengaruh Struktur Pengendalian Intern dan Sistem Pengendalian Intern Terhadap Efektifitas Penyaluran Kredit Pada Perbankan Syariah Di Kota Palembang. Jurnal Ilmiah Global Masa Kini.

Welson, westwind, harijanto sabijono, inggriani elim. (2015). analisis laporan keuangan sebagai kriteria pemberian kredit oleh PT. Bank Tabungan Negara (persero) TBK. Cabang Manado, 3(3), 1266-1274. 